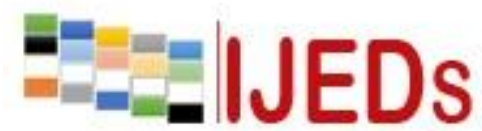

http://ijeds.ppj.unp.ac.id/index.php/IJEDS

\title{
DEVELOPMENT OF WEBLOG BASED LEARNING MEDIA IN INFORMATION AND COMMUNICATION TECHNOLOGY GUIDELINES
}

\author{
* Lenny Erawati ${ }^{1}$, Waskito ${ }^{2}$, Krismadinata ${ }^{3}$ \\ ${ }^{1}$ Graduate Program of Vocation Technology Education Faculty of Engineering, \\ Padang State University, Indonesia \\ ${ }^{2}$ Lecture Faculty of Engineering, Padang State University, Indonesia \\ ${ }^{3}$ Lecture Faculty of Engineering, Padang State University, Indonesia \\ Email: ochy.oliviaoktorie@gmail
}

*Corresponding Author, Received: November 12, 2019, Revised: December 10, 2019, Accepted: December 21, 2019

\begin{abstract}
This research aims to develop weblog-based learning media on information and communication technology (ICT) guidance and reveal its validity and practicality. This type of research is a research development with a 4-D (Four D) model, namely Define, Design, Develop , and Disseminate. The instrument used was a questionnaire in the form of a questionnaire of validity and practicality. weblog based learning media on information and communication technology guidance is validated by 2 experts, namely 1 material expert and 1 media expert . Practicality weblog-based learning media on information and communication technology guidance is carried out on teachers and students of SM A N 1 Tujuh Koto Sungai Sarik . The results of the validity test show that weblog-based learning media on information and communication technology guidance is included in the valid category. Based on practicality test by the teacher and students of SM A N 1 Tujuh Koto Sungai Sarik shows that the media has a very high practicality category. Based on the results of this study, it can be concluded that the weblog-based learning media on information and communication technology guidance is considered valid and practical .
\end{abstract}

Keywords : Media, Weblogs, Information, Communication Technology, 4-D

\section{INTRODUCTION}

The size of the success of the learning process can be seen from the achievement of competency standards and basic competencies. ICT at the SMA / MA level has competency standards as a measure of achievement of learning outcomes. ICT guidance competency standards for class X SMA / MA five standards, namely: 1) 


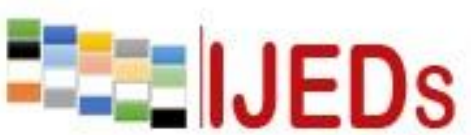

http://ijeds.ppj.unp.ac.id/index.php/IJEDS
International Journal of Educational Dynamics

Vol. 2 No. 1 (pp. 84-90) Desember 2019

p_ISSN 2655-4852

e_ISSN 2655-5093

students have the ability in basic computer operations; 2) students have the ability to understand the functions and work processes of various ICT equipment ; 3) students have the ability to understand the terms of use of ICT ; 4) students have the ability to use the Computer Operating System (OS); and 5) students have the ability to use word processing software.

The problems arise pa da ICT learning will have an impact on student achievement according to the standard of competence. Sumaryati (2017:4 ) finding textbooks and books LKS (student worksheet) still dip akai in the process of learning, with a practicum in the computer lab. Static textbooks and worksheets do not provide up-to-date information that is constantly developing as a result of the progress of science and technology. The achievement of learning objectives is strongly influenced by the book as a source of teaching material. The development of a very dynamic environment will affect teaching material (Asi 2017: 11). On the other hand books as a source of student learning are very limited in terms of material (Mahendra 2014: 11). In response to this, students and students look for additional learning material sourced from the internet. The search results vary among fellow students so that the material is expected to be less complete and make the process pemb elajaran not optimal

Teachers lacking $\mathrm{m}$ emanfaatkan ICT in the learning process. Though the development of ICT greatly influences the development of learning media. By utilizing ICT the learning process can be done anywhere in a variety of different places not only in the conventional form in the study room. With learning utilizing ICT media, the learning process can involve a larger community (Wimboasto, 2017: 2 56) and have advantages, where students are more independent in learning, flexibility in time and place, assignment of assignments and access to teaching material that is relatively easy, feedback from lecturers (Fandianta, 2013: 67). There is a positive influence on the use of ICT in the form of a system as a medium and source of learning on student achievement.

Shifting the learning model that makes the learning center of students from the teacher as the center of learning and the daily development of students who wrestle with the internet world, has an influence on learning patterns. These conditions make educators use digital technology in the learning process to satisfy students and improve 


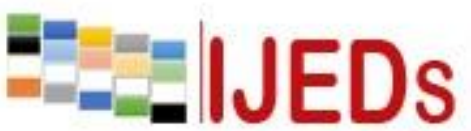

http://ijeds.ppj.unp.ac.id/index.php/IJEDS
International Journal of Educational Dynamics

Vol. 2 No. 1 (pp. 84-90) Desember 2019

p_ISSN 2655-4852

e ISSN 2655-5093

learning outcomes (Hartono, $2014: 121$ ). The integration of weblog media with social media facebook shows the effectiveness of learning activities. This is done through the educator's weblog integrated with students' facebook groups. (Hartono, $2014: 121$ ).

Asyhari and Rahmi Diani (2017 : 21 ), Nopriawan Berkat Asi (2017 : 15 ), Hartono (2014 : 126 ), and Andi Fatmayanti (2014 : 41 ). Asyhari research and Rahmi Diani (2017 : 21 ) showed an increase in communication interactive between educators with learners this case as a result of the conduct of variety and enrichment to the menu or features that support and enhance the interest of learners. The development of this weblog still has shortcomings in the availability of information, including in the form of reference videos, links to other wider sources

Asi (2017 : 11 ) has developed a blog with specificity related to food chemistry. In terms of the material menu, the subject matter displayed in the blog is quite comprehensive. This blog needs broader development of some features, including completing videos, assignments, syllabus, contacts and lecture calendar.

Hartono (2014: 126 ) through the development of weblogs has advantages in integrating the use of media so s ial facebook with weblogs as a learning medium. This has a significant impact on learning outcomes. This blog needs to be developed further by completing several menus or enrichment features so that it is more comprehensive towards the development of instructional media. Some menus or features that need to be developed include syllabus, quiz, and video. While Andi Fatmayanti (2014 : 43 ) developed a weblog for career planning. This blog has advantages in terms of information material related to career planning. This blog needs further development by adding several menus or features such as discussion forums

The development of weblogs in addition to paying attention to ICT competencies also pay attention to several research weblogs that already exist in different subject matter, especially in terms of the features and menus that are displayed. The features and menus that are displayed include assignments, syllabi, contacts and educational calendars, reference videos, links to other wider sources and discussion forums. With the development of weblog -based learning media on ICT guidance it is expected that there will be an influence for improving student learning outcomes from previous ones. 


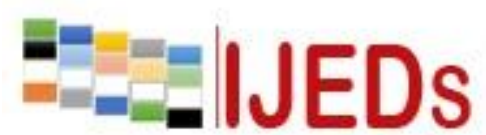

http://ijeds.ppj.unp.ac.id/index.php/IJEDS
International Journal of Educational Dynamics

Vol. 2 No. 1 (pp. 84-90) Desember 2019

p_ISSN 2655-4852

e_ISSN 2655-5093

\section{METHOD}

The type of research used is research and development. The development model used is a 4-D (Four D) model which is a development model of learning tools. S. Thagarajan, Dorothy S. Semmel, and Melvyn I. Semmel have developed this model. The Four D model consists of 4 stages of development namely Define, Design, Develop , and Disseminate or be adapted into a 4-D model . Considerations using this model are : Simple, that is easily implemented by people in doing development ; More relevant is used as a basis for developing learning tools ; The stages of research are clearer and more systematic; The development process involves expert judgment so it is hoped that the products produced are more tested.

Data validity test ber ity instrument of data that is filled by a validator who is an expert on media and subject matter experts teaching. Feedback and suggestions from validator referred to shortly become the material for revision of instructional media TI $\mathrm{K}$-based weblog until the end of instructional media TI K -based weblog is declared valid and feasible in the activities of the research. Following are the results of the questionnaire data from the results of expert validation testing.

The results of the assessment of each aspect provided by the validator were analyzed using the statistical formula Aiken's V. The results obtained were validation values of the product design produced. In the practicality phase, this is carried out on users, namely teachers and students. Practicality test data based on teacher responses is to measure the teacher's response to the practicality of the use of developed media . Practicalities test data based on the response of students is done for me see the response of students to the practicality pe $\mathrm{m}$ a kai 's media developed

\section{RESULTS AND DISCUSSION}

Practicality test data based on teacher responses is to measure the teacher's response to the practicality of the use of developed media. The results of the teacher practicality test on weblog -based ICT learning media are shown in Table 1 below. From Table 1 it can be averaged the acquisition of weblog -based ICT learning media practicality test from the teacher's response of 93,6\% (appendix 7, page 122). Based on the aforementioned data it can be concluded category "Very Practical" can be given to me he was learning was developed. So that the representation of the data shows that 


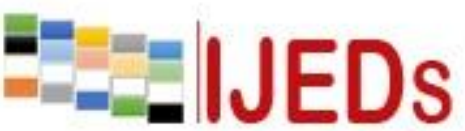

http://ijeds.ppj.unp.ac.id/index.php/IJEDS
International Journal of Educational Dynamics

Vol. 2 No. 1 (pp. 84-90) Desember 2019

p_ISSN 2655-4852

e_ISSN 2655-5093

pe benefits of an instructional media ICT- based weblog very m embantu $\mathrm{p}$ ime Frame learning activities for teachers .

Table 1 . Teacher Practicality Test Results

\begin{tabular}{|c|c|c|c|}
\hline No & $\begin{array}{c}\text { Assessment } \\
\text { Aspects }\end{array}$ & Average value & Category \\
\hline 1 & Quality & $92 \%$ & Very practical \\
\hline 2 & $\begin{array}{c}\text { Media } \\
\text { Characteristics }\end{array}$ & $95.4 \%$ & Very practical \\
\hline 3 & The benefits & $93.33 \%$ & Very practical \\
\hline & Average & $93,6 \%$ & Very practical \\
\hline
\end{tabular}

Practicalities test data based on the response of students is done for me see the response of students to the practicality pe $\mathrm{m}$ a kai 's media are developed. The results of students' practicality tests on weblog -based ICT learning media can be found in Table 2 below.

Table 2 . Student Practicality Test Results

\begin{tabular}{cccc}
\hline No & $\begin{array}{c}\text { Assessment } \\
\text { Aspects }\end{array}$ & Average value & Category \\
\hline 1 & Product Quality & $89.9 \%$ & Very practical \\
2 & The benefits & $91.8 \%$ & Very practical \\
\hline & Average & $91,13 \%$ & Very practical \\
\hline
\end{tabular}

From Table 2 an average value of the practicality of weblog -based ICT learning media is obtained from student responses of 91 , $13 \%$ (appendix 9 , page 127 ). Based on these data d apat diamb i 1 to conclusions media learning entry in the category "S angat Practical". So the representation of the data shows that weblog -based ICT learning media really helps students in implementing the learning process.

\section{The Validity of ICT Based Learning Media Weblogs}

The validation of the weblog-based IT K learning media was obtained from the validator responses about the validity of the weblog -based ICT learning media developed. Validators were 2 people, including one person for the material validator and one person from the learning media validator. Validator assessment is based on the validity questionnaire filled out by each validator and discussion by showing the weblog -based ICT learning media. In the media validator gives a validation value of 0,93 , which is declared valid. While the material validator gives an assessment of 0,87 with the declared valid. Based on the assessment of the learning media validator and the learning material validator, a conclusion is drawn that the learning media developed are 


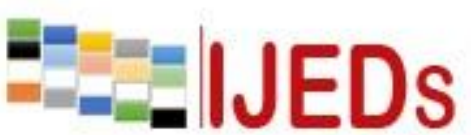

http://ijeds.ppj.unp.ac.id/index.php/IJEDS
International Journal of Educational Dynamics

Vol. 2 No. 1 (pp. 84-90) Desember 2019

p_ISSN 2655-4852

e_ISSN 2655-5093

already worth testing in the field as one of the sources of learning in the eyes of ICT subjects.

Referring to the opinion of Sudjana and Ahmad Rival (2013:43) se b u ah instructional media should qualify easily seen ( visible), interesting ( interesting) and precise ( accurate), the media should be able to read easily, designed to draw so can motivate students, as well as the media have to conform late to the characteristics of the learning material.

\section{Practicality of ICT Based Learning Media Weblogs .}

Data prakti kalitas media weblog-based ICT learning is taken through a trial conducted pa d a SMA Negeri 1 VII Koto Sungai Sarik. The assessment of the practicality of weblog-based ICT learning media filled by teachers / practitioners obtained $92 \%$ results for the aspects of product quality, $100 \%$ for Media Characteristics, and $93.33 \%$ for the benefits aspects with very practical categories for each aspect. Instructional media practicality of ICT -based weblog is also seen from the students' responses through the results of a questionnaire which amounted to $89,38 \%$ for the quality of the products „, $81,04 \%$ of the aspects of $\mathrm{M}$ anfaat. With the practicality category is very practical. According Sudjana and Ahmad Rival (2013 : 43 ) a medium of learning should blow has i value practicality and simplicity so it could be in the benefit not it easy to achieve learning objectives.

\section{CONCLUSION}

The learning media of weblog-based information and communication technology is declared valid by the material validator and the media validator, making it feasible to be used in the field as an online learning resource. Weblog learning media information and communication technology is declared practical by users, namely students and teachers through the distribution of practicality questionnaire, after using the media, the learning media is able to facilitate and increase student learning desires.

Weblog learning media information and communication technology is expected to be able to do dissemination and use in other schools so as to know the appropriateness of the use of weblog-based information and communication technology learning media. 


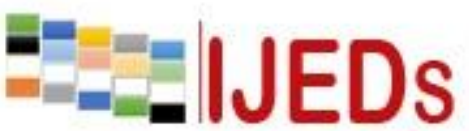

http://ijeds.ppj.unp.ac.id/index.php/IJEDS
International Journal of Educational Dynamics

Vol. 2 No. 1 (pp. 84-90) Desember 2019

p_ISSN 2655-4852

e_ISSN 2655-5093

\section{REFERENCES}

Asi, Nopriawan Berkat. 2017. "Pengembangan Bahan Ajar Kimia Bahan Makanan Berbasis Web". Jurnal Pendidikan Teknologi dan Kejuruan Balanga Volume 6 No. 2 Juli - Desember 2017 : 10 - 15.

Asyhari, Ardian. Rahma Diani 2017. Pembelajaran Fisika Berbasis Web Enhaced Course: Mengembangkan Web-Logs Pembelajaran Fisika Dasar I. Jurnal Inovasi Teknologi Pendidikan Volume 4 Nomor 1: 14 - 25.

Fandianta. 2013. Pemanfaatan E-learning Sebagai Media Pembelajaran Mata Kuliah Promosi Kesehatan di Jurusan Keperawatan Poltekkes Kemenkes Palembang. Tesis. Yogyakarta: Program Pasca Sarjana Fakultas Kedokteran Universitas Gadjah Mada.

Fatmayanti, Andi. 2014. Pengembangan Media Blog Sebagai Sarana Informasi Untuk Meningkatkan Kemampuan Perencanaan Karir di SMAN 1 Bulukumba. (online) http://eprints.unm.ac.id/544/, diakses 17 Mei 2018.

Hartono. 2014. Efektivitas Weblog dan Facebook Terintegrasi Untuk Pembelajaran Virtual. (online) https://journal.uny.ac.id/index.php/cp/article/view/1868, diakses 17 Mei 2018.

Mahendra, I Gede Jaka. 2014. "Pengembangan Media Pembelajaran Berbasis Blog Pada Mata Pelajaran Teknologi Informasi dan Komunikasi Kelas VII SMP Negeri 1 Sukasada". Jurnal ... Volume ... No. ... : 10 - 15.

Sudjana, Nana dan Ahmad Rivai. 2013. Media Pengajaran. Bandung: Sinar baru Algensindo

Sugiyono. 2012. Statistika Untuk Penelitian. Bandung: Alfabeta.

.2014. Metode Penelitian Kuantitatif, Kualitatif, dan $R \&$ D. Bandung: Alfabeta.

Sukmadinata, Nana Syaodih. 2007. Landasan Psikologi Proses Pendidikan. Bandung: PT.Remaja Rosdakarya.

Sumaryati, Hevi. 2017. Pengelolaan Pembelajaran Teknologi Informasi dan Komunikasi Berbasis Web Pada Materi Internet di SMP Negeri 1 Plupuh. Tesis. Surakarta: Program Studi Magister Administrasi Pendidikan, Sekolah Pasca Sarjana Universitas Muhammadiyah.

Wimboasto, Matheas Agus. 2017. "Penggunaan Teknologi Informasi dan Komunikasi untuk Peningkatan Prestasi Belajar Geografi Siswa Kelas X Di SMA Negeri 1 Sungai Tabuk". Jurnal Pendidikan dan Pembelajaran Ilmu Sosial Volume 6, Nomor $2: 254-269$. 